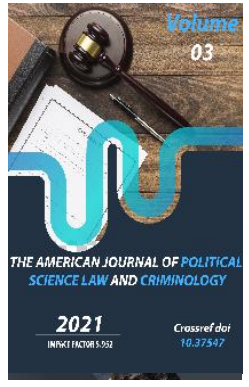

Journal Website: http://theamericanjour nals.com/index.php/taj pslc

Copyright: Original content from this work may be used under the terms of the creative commons attributes 4.0 licence.

\section{State Role And Securities Market Development In Uzbekistan}

\author{
Said Gulyamov \\ Doctor Of Law, Professor, Department Of International Private Law, Tashkent State University \\ Of Law, Tashkent, Uzbekistan \\ Otabek Narziev \\ Ph.D. In Law, Department Of International Private Law, Tashkent State University Of Law, \\ Tashkent, Uzbekistan \\ Sadoqat Safoeva \\ Candidate Of Law, Judge Of The Tashkent City Civil Court, Uzbekistan \\ Jahongir Juraev \\ Candidate Of Law, Judge Of The Tashkent City Administrative Court, Tashkent, Uzbekistan
}

\title{
ABSTRACT
}

In the Uzbekistan capital market, the state has a significant role as regulator and principal shareholder. The state actively participates in the capital market through its SOEs and banks that issue, own, manage various securities, and render intermediary services in the financial market. As well as the state sets rules to regulate market relations through authorized bodies that are also responsible for the fairness of dispute resolution. Consequently, a high level of direct and indirect state participation in securities market relations suggests the prevalence of general administrative principles over market principles. In such conditions, one of the main tasks of implementing market principles in the securities market and improve equity financing would be to reduce state share and administrative methods. Thus, it is necessary to hold extensive and comprehensive reforms underpinned by sound theory to get proper understanding and direction. In this regard, this chapter provides an outline of the theoretical bases of state participation in the economy, an overview of the state's role and the extent of state ownership, an analysis of the main SOE problems, and provides perspectives of future SOE reforms in selected CIS countries.

\section{KEYWORDS}

Market principles, SOE reforms, planned economies, economy and securities, liberalization and privatization reforms.

\section{INTRODUCTION}

1. Outline of theories on state participation in the economy
In general, the modern market economy cannot exist without the state's economic 
activity. Especially during the last two decades, the state's presence in business relations as a unique subject has only increased. For instance, according to Bremmer, "governments, not private shareholders, already own the world's largest oil companies, and control three-quarters of the world's energy reserves." [1] In the late 70 s of the last century, SOEs' share in developed countries accounted for about 7\% of GDP; in non-socialist developing countries, almost $12 \%$, and in planned economies, around 90\% [2]. Despite the privatization movements in the last three decades, SOEs still significantly impact key industries of the economy, market capitalization, investment, and employment, especially in post-Soviet countries. In such conditions, state presence in the economy is a crucial issue that generates fruitful discussion and controversy.

The recent history of the main discussion on the state's involvement in market relations goes to the classics of economic theory (A. Smith, D. Ricardo, et al.), according to which the market economy should develop by selfregulation, that is, without the involvement of any external forces, including the state [3]. The classical model assumes minimal intervention in the economy and is based on the notion of Adam Smith whereby the state is the 'night watchman' of a market economy. Following this concept, the business produces and consumes. The state is engaged in protecting property rights, ensures the observance of market principles, and strongly reacts to the deviation of rules, up to the use of force (law, court, army, police, and so on). However, the crisis of the capitalist economy and securities market crash in 1929-1933 marked the end of the free enterprise 'era.' It reflected the inability of the market system to develop itself without state involvement.

The Keynesian model was presented as a remedy for the economic crisis. It assumes active and, as far as possible, maximum government intervention in the economy to minimize cyclical fluctuations, unemployment, inflation, and loss of resources and products of all market participants. In his 'The General Theory of Employment, Interest, and Money, Keynes questioned the assumption that selfregulation is automatic in a market economy and justified the need for government intervention in economic processes [4]. This theory received a practical application in the US economy (in the 50s) and brought specific, definite results in economic activity. Later, Keynes's theory of state regulation formed the basis of the economic policy of almost all developed capitalist countries.

In the 1970s-80s, when excessive state intervention in the economy was considered responsible for slowing down the development of social production, neoclassical economic ideas have again become relevant and remain so to this day. According to this doctrine freeing up markets and reducing direct state intervention make economies more flexible and creative. They inspired liberalization and privatization in many developed and developing countries and even political revolution in many socialist countries [5]. According to Chang, "despite the continuous widening of their scope, neoliberal reform programs have failed to produce expected results". Neoliberalism failed in generating faster growth instead of increased income inequality and economic instability [5]. By the end of the 20-century neoclassical theory was no longer dominant. 
Recent research suggests that globalization has increased government sectors around the world [6]. The latest tendency in the attitude of the world's largest economies to a maximum usage of state leverages in economic relations may change the further direction of theories on the state's role in the marketplace.

\section{Overview of the state's role in CIS countries}

Almost three decades earlier, the state in all CIS countries had an absolute role in market regulation and economic activity. Around 80 years CIS countries experienced a centrally planned economy and administrative command ruling in their economic, social, and political life. During the command and regulatory system, the state was the principal buyer of products, the central monopolist, and the exclusive distributor of resources, financial means, equipment, and human resources. Enterprises sought different ways of access to these resources. Very often, the situation developed so that some received enough resources, sometimes in excess, and others were deprived of them. In the absence of competition, enterprises with resources were not interested in their rational use, and enterprises deprived of the necessary means could not intensively develop their production.

It seemed that the market economy could change that situation, but despite the almost three decades of reforms, most CIS countries consider liberalization and privatization reforms very cautiously. As a result, today, most CIS countries have dominant (i.e., more than fifty percent of) state shares in their economy and a tight market regulation system. For instance, in Russia, by the end of 2015, the share of SOEs in the country's GDP was almost seventy percent, in Kazakhstan, sixty percent, and in Uzbekistan, according to official statistics, Around twenty percent [7]. Also, in all countries examined here, banks dominate in the financial sector, and the state share in bank ownership is around eighty percent. This has great significance for the further development of the securities market in these countries, where banks play a considerable role in market relations as securities issuers, shareholders, and intermediaries.

As for the reasons of high state involvement in the economy, several factors could be listed, including historical, geographical, legal/juridical, political, and economic. Historical elements relate to the heritage of the centrally planned economy that was in operation for more than a century. The geographical aspect is explained through natural resource abundance in the countries examined. Usually at the initial stage of development the management and extraction of natural resources is the responsibility of public entities rather than private ones. Another main factor by which the dominance of state regulation and state presence in the economy in CIS countries is explained is through legal origin theories. For instance, several scholars in their numerous studies found that civil law countries were associated with a greater state ownership and regulation than common law countries [8]. Political and economic factors mainly relate to the weak regulatory framework and the transitional stage of the economy that is usual for countries with identical or similar characteristics. In other words, there will be more demand for the state's paternalistic, 
welfare, and social roles in the transition period. However, the limits of the transition period and state participation content may differ based on a country's features. To get a picture of such features, an attempt to outline the level of state ownership in the case of Uzbekistan, Russia, and Kazakhstan is offered below.

\subsection{State ownership level in Uzbekistan}

The state ownership level issue is one of the puzzles that occur in studying the issue of
SOEs in Uzbekistan. This puzzle is mainly caused by inconsistent data and statistics, including from official sources, on the level of state ownership. The analyses show that the socially-oriented market economy and gradual privatization reforms have significantly influenced SOE reform in Uzbekistan. According to official statistics, the share of state ownership in the GDP structure of the country decreased from 41 percent in 1995 to 19 percent in 2017 (Figure 2).

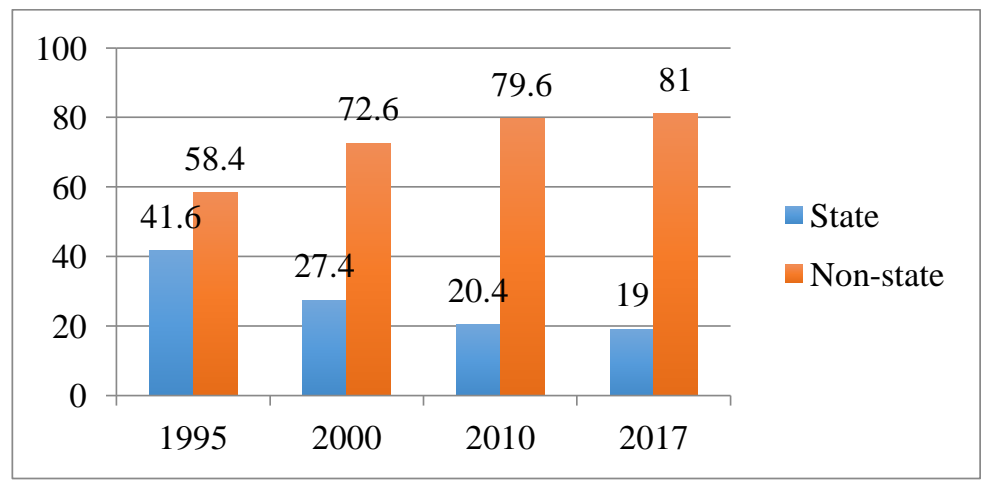

Figure 2. Structure of Uzbekistan GDP by ownership form Source: State Statistic Committee of Uzbekistan.

The above figures are based on the Report of the Uzbekistan Statistics Committee, but attempts to scrutinize the figures by checking other sources, including official sources, give rise to serious doubts about these figures' reality and reliability. According to the State Agency for State Property Management, in the current period, the number of enterprises with state participation is 2,965 , the nominal value of state assets is equal to 111.4 trillion sums, and their share in GDP is 55 percent [9]. An attempt follows in the below to interrogate the statistical data in order to understand the real share of state ownership in the GDP of Uzbekistan. First, an examination of the GDP structure (figure 3) suggests that in 2016 almost half of the GDP relates to the services sector, nearly one-third to industry, and about 18 percent to agriculture. 


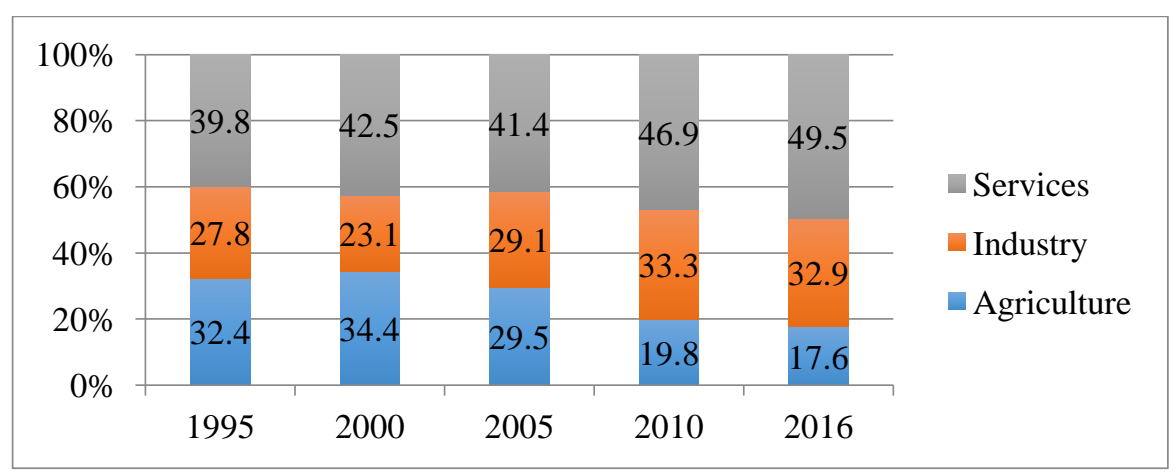

Figure 3. Changing dynamics of GDP structure of Uzbekistan Source: State Statistic Committee of Uzbekistan.

The next step of the investigation is to look inside the services sector and analyze its structure. The following chart (figure 4) demonstrates the main industries within the services sector of Uzbekistan, where transport services lead with around 40 percent of the share, trade covers more than one-third of the services sector, almost one fifth goes to finance, and about 10 percent belongs to the communication services. Moreover, were one to dig deeper into specific service sectors, it would appear that the state has a significant share in each of them. For instance, in the transport sector, airways and railways facilities are entirely owned and managed by SOEs, in the banking sector, almost 80 percent of services and assets belong to the state (figure 5), and in the trade sector, more than 65 percent of export accounts for SOEs or government-related entities (figure 6).

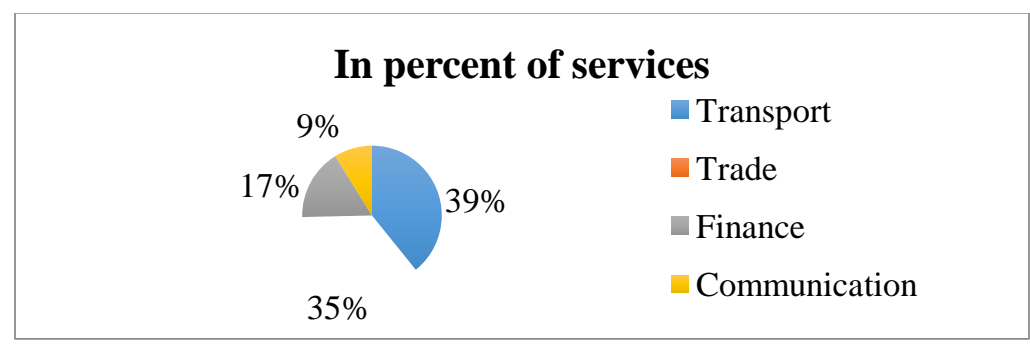

Figure 4. Services structure of Uzbekistan GDP (2017)Source: State Statistic Committee of Uzbekistan.

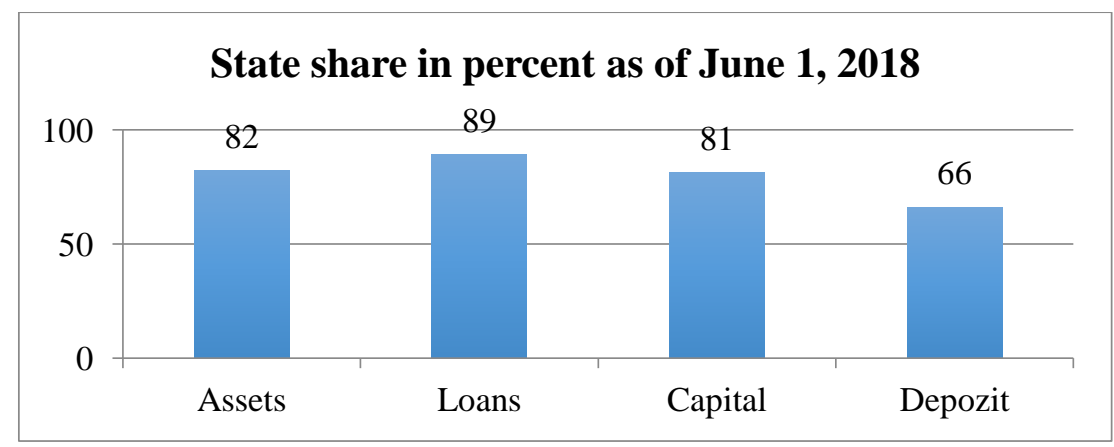


Figure 5. State ownership in commercial banks of Uzbekistan

Source: Central Bank of Uzbekistan, Information on the leading indicators of commercial banks activity as of June 1, 2018.

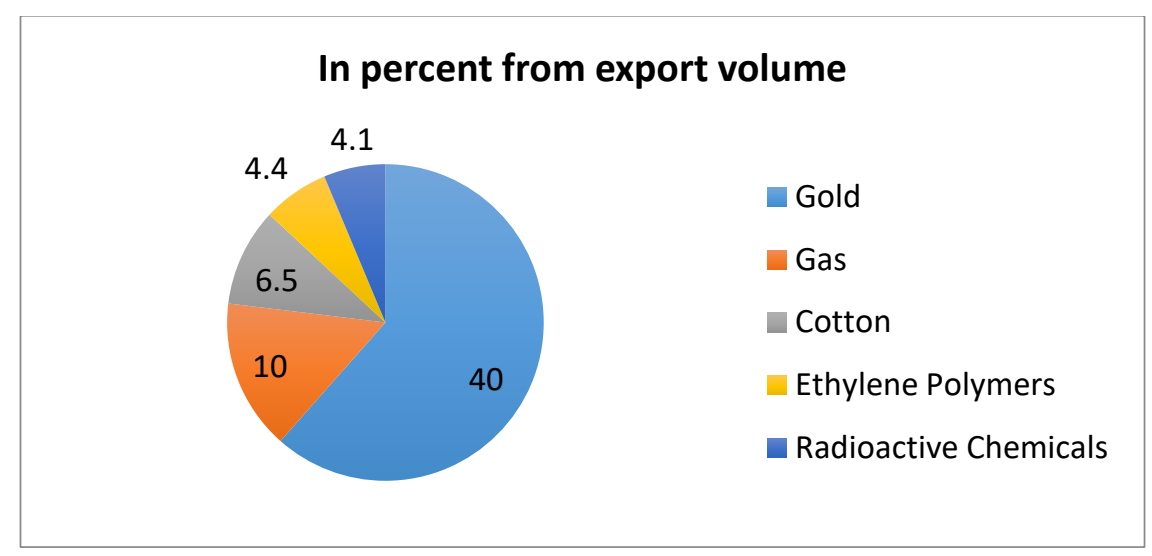

Figure 6. State share in Uzbekistan export (2016)

Note: Export volume in 2016 was USD 7.11 billion.

Going further on with seeking to verify the figures on the state share in Uzbekistan's GDP, it is necessary to analyze the structure of the industry sector. The following chart shows that Uzbekistan's industry sector is quite diversified (Figure 7). However, in all sectors of industry, SOEs have a significant share. For instance, in the mining sector, one of the largest companies is Navoiy Mining and Metallurgical Combinat, which is the primary producer and exporter of uranium and precious metals, including gold. Other giant companies in the mining sector include Bekobod Metallurgical Combinat and Angren Metallurgical Combinat in which the state owns a significant share. In the ownership structure of textile, chemicals, automobile, electricity, and gas sectors, a similar situation is witnessed.

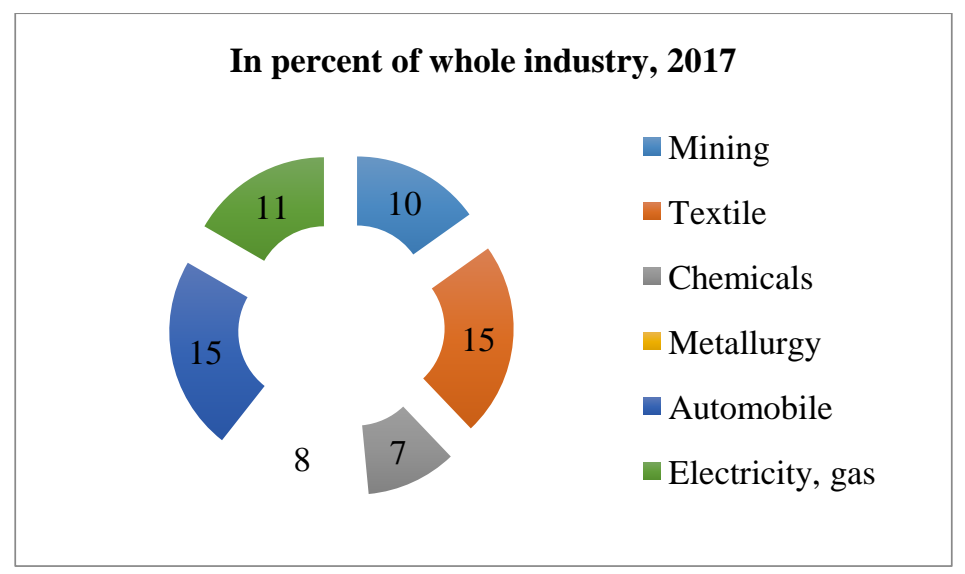

Figure 7. Industry structure of Uzbekistan GDP

Source: State Statistic Committee of Uzbekistan. 
Next, an attempt to identify state ownership in the number of companies could also shed further light on the question of state involvement. By January 1, 2017, there are 213,089 acting companies (excluding farmers) in Uzbekistan, $1.1 \%$ of which are unitary enterprises totally owned by the state (i.e., the state holds $100 \%$ of their shares). The main organizational-legal form of operating companies is that of Limited Liability Company (LLC) - namely, $57 \%$ of companies (Figure 8 ). There are only 2,302 large companies, which cover around 1.1 percent of the total quantity of acting businesses.

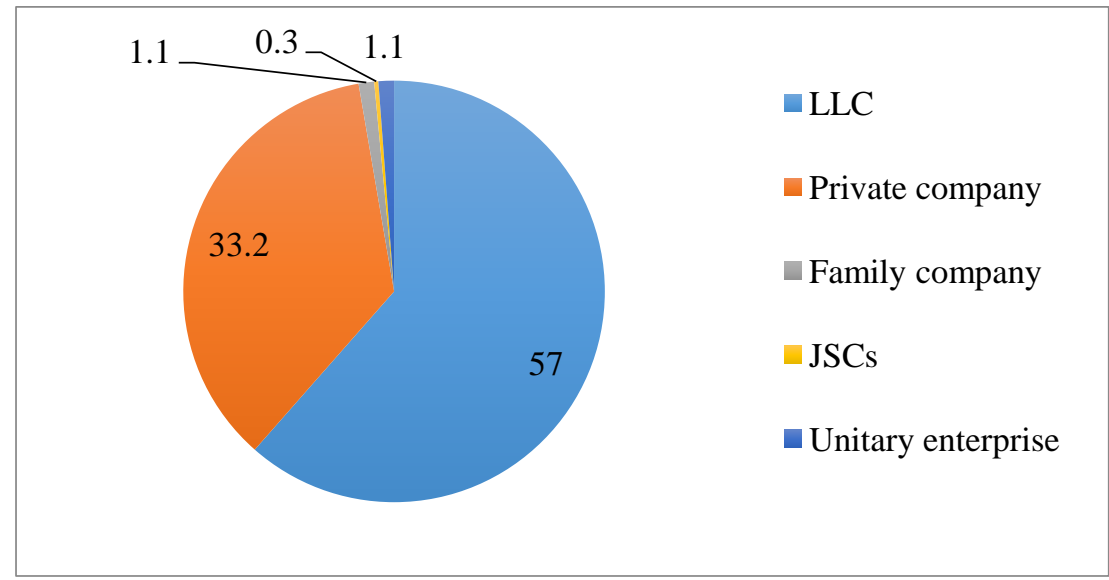

Figure 8. Classification of companies in Uzbekistan by their legal-organizational form (by Jan. ${ }^{\text {st }}$ of 2017)

Source: State Statistics Committee of Uzbekistan

The following table presents the summarizing picture of ownership structure in the companies, which are mainly JSCs, acting in the industry sector (table 6). From the table it is clear that the state share in these JSCS, including SOEs shares, exceeds 80 percent.

Table 6. State share in JSCs of Uzbekistan, by January 1, 2017

\begin{tabular}{|c|c|c|c|}
\hline $\begin{array}{c}\text { Structure of stock by nominal } \\
\text { price }\end{array}$ & USD billion & Number of JSCS & Share in \% \\
\hline State share in JSCS & 2.78 & 158 & 73.01 \\
\hline SOEs share in JSCs & 0.43 & 326 & 11.34 \\
\hline Total & 3.21 & 484 & 84.35 \\
\hline Private sector share & 0.6 & 175 & 15.65 \\
\hline
\end{tabular}

Source:Concept of Development Secondary Securities market in Uzbekistan in 2017-2018 
By quantity, JSCS comprise only 0.3 percent of all existing companies (figure 8), but by financial status - they are much larger than LLCs. According to legislation, the minimal amount of charter capital of JSCs should be no less than USD 400,000, while in the case of LLC this amount is 40 times of minimum wage, which will be around USD 920 [10].
The following chart demonstrates a change of the quantity of SOEs in the last five years (figure 9), where there has been an increase both in the quantity of JSCS and LLCS until 2015, and a significant decrease in the previous two years.

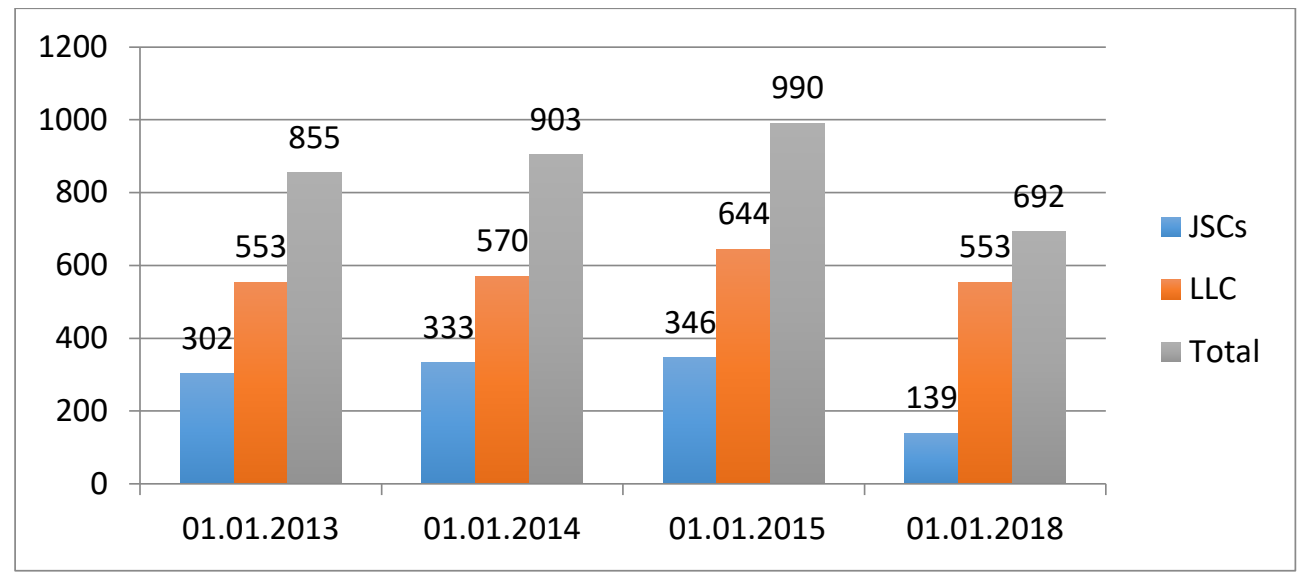

Figure 9. Change of SOEs' quantity of Uzbekistan in the last five years

\section{Source: State Committee of Uzbekistan for Assistance Privatized Enterprises and Development of Competition.}

Also, lastly, the agriculture sector, which, according to official statistics, covers around one-fifth of the country's GDP (figure 3). Despite several reforms and attempts to diversify ownership in the sector, the state remains the principal owner. According to the Constitution of Uzbekistan, the land amounts to national wealth, and, consequently, it is outside the scope of privatization. The Law on Privatization and Denationalization (1991) also prohibits the privatization of land and related resources. Farmers produce agricultural products in the leased land, which at any time and for any reason may be taken over by local and central authorities. In most cases, farmers do not have actual choice in terms of crop, marketing, pricing, and selling of their crops. Usually, local authorities administratively order what kind of product/crop should be sown, and

at what price it should be sold. In most cases, authorities do not take responsibility for selling the product that was grown by administrative pressure, without any marketing analysis. Consequently, farmers waste time and funds - that in most cases were borrowed from state-owned commercial banks -, and lose confidence. In sum, there is absolute state ownership over the land in the agricultural sector, which is the primary means for the organization of business in that sector, and there is actual state control over farmers' activities. 
The scrutiny and interrogation of the figures mentioned above concerning state ownership in the GDP of Uzbekistan suggests the presence of inconsistencies between official data and other sets of data and statistics. For instance, the recent Resolution of the President of Uzbekistan 'on Measures to Improve the System of State Assets Management, states that: "state-owned enterprises and other legal entities with the predominant share of state in the capital fund play a significant role in the national economy, occupying key positions in priority sectors, primarily in the fuel and energy, agroindustrial, mining, engineering, transport, chemical industry, [and in] telecommunications".

There are some enlightening conclusions in the EBRD, US Government reports, and in the ADB concept paper. According to the latest EBRD country assessment, "the state continues to play a dominant role in the economy. Progress under the recently renewed privatization programme has been minimal". The US Government Report of 2018 also mentioned SOE dominance in a range of sectors including in "energy (power generation and transmission, and oil and gas refining, transportation and distribution), metallurgy, mining (non-ferrous metals and uranium), telecommunications (fixed telephony and data transmission), agriculture (cotton processing), machinery (the automotive industry, locomotive and aircraft production and repair), and transportation (airlines, railways, municipal public transportation)" A recent ADB concept paper also mentioned that "SOEs dominate all the important segments of the economy, and thus leave little space for the private sector." However, as mentioned above, the recent reforms suggest that the current situation in Uzbekistan will no longer remain as it is. The extent, intensity, and content of the intended reforms may help mitigate SOE problems within Uzbekistan and lead to the reconsideration of the issue of SOEs by the other countries within the CIS region.

\subsection{Latest reforms}

On October 27, 2020, Presidential Decree No. UP-6096 "On Measures for Accelerated Reform of Enterprises with State Participation and Privatization of State Assets" was adopted.

According to the decree a number of SOEs are subject to transformation. Among them 32 large SOEs and business associations and 39 enterprises with the participation of the state. The reform content includes introduction of corporate governance and financial audit; at 62 state assets, targeted pre-privatization preparation programs will be implemented; in 479 enterprises, state blocks of shares (stakes) are fully sold through public auctions; and15 state-owned real estate objects will be sold to the private sector.

Since 2017 there has been a sharp increase in the scale of privatization: from 178 objects in 2016 to 842 in 2019. The presidential decree notes that the delay in the transition to market mechanisms of some industries and large enterprises, in which the state's share remains, prevents the establishment of production of new types of competitive products, the introduction of advanced technologies, an increase in labor productivity, the creation of new jobs with the active attraction of private capital.

\section{The share of SOEs in Russia}


The public sector also plays a significant role in the Russian economy. The share of SOEs' revenue in terms of the total revenue of the largest companies has grown steadily in recent years. According to the recent report of the Russian Federal Antimonopoly Service (FAS), the state's presence in the Russian economy is proliferating. Thus, the contribution of SOEs to GDP grew to $70 \%$ in 2015 from 35\% in 2005, and the number of state and municipal unitary enterprises has tripled in the last three years. According to the data for 2011, the largest share of the state's presence was observed in the transport sector (73\%), banking (49\%), oil and gas sector (45\%), housing and public utilities (35\%), mechanical engineering (15\%), and in the telecommunications sector (14\%) [11]. The dynamics of the sectorial structure of SOEs ranked by Expert RA (i.e., Russia's oldest credit rating agency) according to the annual accounts for 1998, 2005, 2009, and 2014 shows an increase in the state's share in the engineering, oil, and gas, and banking sectors. The presence of the state has noticeably decreased however in the chemical and petrochemical industry. The state is practically not represented only in the trade, nonferrous, and ferrous metallurgy sectors [12].

At the same time, the state demonstrates inflexibility and is very reluctant now to part with its property. The FAS report, for example, notes that in 2012 the list of the largest companies subject to privatization was expanded. The state was going to significantly reduce its share in them, or even wholly withdraw. However, plans have changed, and now the state is not going to part with corporate control [12]. According to Russian Prime Minister Dmitriy Medvedov “since 2013, we have doubled the number of unitary enterprises, while different orders provide for their further reduction." As FAS emphasizes, such enterprises are still being created in markets with relatively developed competition, where the use of administrative resources and budget financing negates the efforts of more active players. It should be mentioned that FAS is more active in reducing anticompetitive actions and the dominant position of state companies in Russia compared with the same authorities in Uzbekistan. For instance, recently FAS proposed several bills on reducing the state share of, and promoting competition in, the market. A separate bill of the FAS proposes to prohibit the creation of unitary enterprises in competitive markets, and from February 1, 2018, to eliminate such an organizational and legal form, which is considered a relic of the planned economy system. The enormous growth of state and municipal enterprises is the most dangerous trend in terms of the general strengthening of state monopoly in the economy, which, according to FAS, over the past three years their number has doubled. A unitary enterprise, by entering a competitive market, monopolizes it after a certain period, and private business is consequently discriminated.

Furthermore, the FAS prepared a draft presidential decree approving the national plan for the development of competition in 2017-2019, which it submitted to the government for adoption [13]. The main threat to competition, according to the FAS, comes from the state itself, and a presidential decree needs to reduce state participation in the economy. The FAS proposes to do this in several ways, and the first is to reduce the market share of state and municipal companies. The government should ban SOEs 
and public enterprises from acquiring new assets, both directly and through subsidiaries. Also, the state should divest itself of all existing SOEs, and not only of the less important ones. According to the draft decree, SOEs should be obliged to develop programs to alienation of core assets. The reality is that these bills may not actually change the situation much given that the FAS's authority is limited against large SOEs that are fully exploiting their lobbying capacity to influence state policy in this matter.

Furthermore, there has been a significant increase in state presence in the financial services of Russia. For instance, while in 2004 the state share in the banking sector had been only $30 \%$, by 2018 it had risen to $70 \%$ from $61 \%$ at the beginning of 2015 [14]. Currently, there is no private bank among the top five Russian banks, and in the top ten, only three, including a branch of a foreign bank. The share of four state-owned banks represented in the top 100 largest companies in 2014, accounted for $86 \%$ of the revenues of all companies in the industry [15]. Since August 2017, the three largest private banks have come under state control, as the Bank of Russia began to seize them through the newly created Fund for the Banking Sector. The nationalization of the banking sector carries severe risks for investors, including the inefficiency of bank management caused by financing industries on political grounds - an action that is not necessarily always economically justified.

State presence in the economy directly reflects the state's share in the country's securities market. According to a recent report, the country's largest SOEs are in the top ten most capitalized stock issuer companies. The total share of the ten most capitalized issuers practically stopped shrinking from 2011, and in 2017 this figure was about $61.5 \%$ of total market capitalization (table 7). For instance, the share of Gazprom, Rosneft, and Sberbank covered over 30\% of the market's total capitalization in 2017. In the period 2007-2014 Gazprom had been the leader concerning capitalization, in 2016 it was Rosneft, and in 2017, it was Sberbank.

Table 7. The list of most capitalized Russian issuers (2017)

\begin{tabular}{|c|c|c|c|}
\hline & Company issuer & $\begin{array}{c}\text { Capitalization in billion } \\
\text { USD }\end{array}$ & \% in total capitalization \\
\hline 1 & Sberbank & 87.61 & 14.06 \\
\hline 2 & Gazprom & 53.35 & 8.56 \\
\hline 3 & Rosneft & 53.30 & 8.55 \\
\hline 4 & Lukoil & 48.99 & 7.86 \\
\hline 5 & Novatek & 35.54 & 5.70 \\
\hline 6 & Noril Nickel & 29.51 & 4.74 \\
\hline 7 & Surgutneftgaz & 20.94 & 3.36 \\
\hline 8 & Gazprom neft & 20.17 & 3.24 \\
\hline 9 & Tatneft & 18.90 & 3.03 \\
\hline 10 & NLMK & 15.35 & 2.46 \\
\hline & Total & 623.2 & 61.6 \\
\hline
\end{tabular}


Source: NAUFOR Report, Russian Stock Market: 2017, Events and Facts, 2018,13

Overall, Russian business attempts to survive in whatever economic space is not yet occupied

by the state. According to a Russian Union of Industrialists and Entrepreneurs survey, $48 \%$ of

Russian companies believe that government considers business as a 'wallet' [16]. It is officials who entrepreneurs consider to be the main enemies of competition. The actions of the authorities are the main reason for the reduction of the number of competitors in the critical sectors of the economy that directly reflects the securities market indicators of the country.

\section{SOEs presence in Kazakhstan's economy}

Kazakhstan's economy is also characterized by the dominance of large SOEs, industrial and financial conglomerates, especially in the gas, transport, electricity, postal, and mobile telecommunication services sectors. There are about 7,000 registered SOEs, of which over a thousand are considered significant, as they employ more than 250 people. As of October 2017 , about $10.3 \%$ of all operating companies in Kazakhstan are either state-owned or involve state participation. In recent years, the share of the state in large companies has significantly increased rather than decrease. Notably, in October 2017, about $46.9 \%$ of all large operating enterprises in Kazakhstan are either wholly state-owned or with partial state participation. This is the highest indicator of the public sector's share in large businesses over the past ten years, while the lowest record was in 2007 when the state share was
$41.7 \%$. The percentage of SOEs in mediumsized enterprises is significantly higher (56.5\%) than in relation to large companies. Despite this fact, the state share in relation to medium-sized enterprises is decreasing.

Kazakhstan has set a goal to reduce the state's share in the economy to $15 \%$ by 2020 , which is the most ambitious privatization program since independence. There is considerable support for the idea that privatization can lead to a significant increase in profitability, company performance, and efficiency. The present privatization program seems extremely ambitious as it is proposes to privatize about 800 companies, including the 'top 65' and some large enterprises.

As for state presence in the banking sector, SOEs and various state funds are still the main creditors of the banking system of Kazakhstan. Together, they account for about a third of the liabilities of banks, for which there are objective reasons, such as a high proportion of the state in the economy, especially in the oil and gas sector. At the same time, the state also takes indirect financial participation in the rehabilitation of loan portfolios through the framework of business support programs, construction, and agriculture. It is difficult for banks to get significant and stable financial resources in a relatively small and poorly diversified economy. The state had been actively involved, through massive government bailouts, in the banking sector in the crisis years of 2009-2010. At present, the state, represented by the government of Kazakhstan and the National Welfare Fund, Samruk-Kazyna, has significantly reduced its share of the banking sector. So while at the 
beginning of 2014, the state controlled $19 \%$ of the total assets of Kazakhstan banks, in 2016 the share of state assets was less than $4 \%$.

On the other hand, state presence in Kazakhstan's securities market is relatively significant. For instance, as of January 2017, second-tier banks invested in securities amounted to 3,217,295 million tenges (c., USD 8.5 billion). More than $76 \%$ of this was spent on government securities of Kazakhstan. However, recent reforms are promising further liberalization of the securities market, reducing state participation in the economy, and creating a competitive market. Some of such concrete measures are determined in the Joint Action Plan on the Development of the Securities market for 2018-2021, which was adopted by the Government and the National Bank of Kazakhstan. According to a report of the National Bank, part of the measures mentioned above has already been implemented. Particularly, actions on the simplification of procedures for issuers to enter the securities market, access to trading for retail investors, substantial liberalization of brokers, and the expansion of investment opportunities of bank-holding companies have all led to a revival of dealing in securities on Kazakhstan Stock Exchange. Despite these reforms, there still are significant problems that require immediate and comprehensive solutions. Below follows an attempt to address-to-address the issue of SOEs in CIS countries by reference to the case of Uzbekistan.

\section{CONCLUSION}

This article has sought to outline the role of SOEs in CIS countries' economy, outline the theoretical basis of state participation in economics, and address some urgent issues connected with SOE activity in Uzbekistan. Among the findings of this thesis is that despite extensive privatization reforms implemented since the 1990s, SOEs are still having a significant role in the economy of Uzbekistan and the other CIS countries examined in this thesis. In most cases, SOEs enjoy privileges and immunities that are not based on their better performance but due to the fact that they belong to the state or staterelated officials. Such exclusive privileges and immunities ultimately distorts market conditions by weakening competition and leading to SOEs abusing their dominant position in the market. A further finding is that one of the core causes of SOE inefficiency is their double-aimed (business and political) feature that should be addressed in subsequent reforms. A crucial conclusion of the research behind this thesis is the recognition that securities market development reforms can provide practical solutions for SOE reforms in CIS countries. Securities market development can assist privatization process with offering more public assets to private owners (through various IPOs and SPOs), which may also lead to increases in the transparency and accountability of SOEs through, for instance, mandatory information disclosure and effective corporate governance systems).

\section{REFERENCES}

1. Bremmer, I. (2009). State capitalism comes of age-the end of the free market. Foreign Aff., 88, 40.

2. Stuenkel, O. (2016). Aldo Musacchio and Sergio G. Lazzarini: Reinventing State 
Capitalism: Leviathan in Business, Brazil and Beyond. Journal of Economic Issues, 50(3), 910-911.

3. Büge, M., Egeland, M., Kowalski, P., \& Sztajerowska, M. (2013). State-owned enterprises in the global economy: Reason for concern. CEPR's Policy Portal. Retrieved, 8, 2017.

4. Keynes, J. M. (2018). The general theory of employment, interest, and money. Springer.

5. Chang, H. J. (2003). Globalisation, Economic Development \& the Role of the State. Zed Books.

6. Meinhard, S., \& Potrafke, N. (2012). The globalization-welfare state nexus reconsidered. Review of International Economics, 20(2), 271-287.

7. Official Report of the Statistics Committee of Uzbekistan about Macroeconomic Indicators for 2017, 5 .

8. La Porta, R., Lopez-de-Silanes, F., \& Shleifer, A. (2013). Law and finance after a decade of research. In Handbook of the Economics of Finance (Vol. 2, pp. 425-491). Elsevier.

9. В июле в Узбекистане начнут выставлять на продажу госактивы. (n.d.). UzDaily.uz. Retrieved June 13, 2021, from https://uzdaily.uz/ru/post/50244

10. ZRU-370-son 06.05.2014. On the introduction of changes and additions to the Law of the Republic of Uzbekistan "On joint-stock companies and protect the rights of shareholders." (n.d.). lex.uz. Retrieved June 14, 2021, from https://lex.uz/docs/2382411\#2383643

11. Y. Tseplyaeva, Y. Eltsov, Half of the Russian Economy is Already in the Public Sector. October 22, 2012.
12. State Participation in Russian Economy: State-owned Companies, Procurement, and Privatization", Analytic Center under the Government of Russian Federation, March 2016, 20.

13. Ю Кувшинова, О., \& Письменная, Е. (2012). Половину экономики России уже составляет госсектор. Ведомости, 6.

14. Yekaterina Mereminskaya., Margarita Papchenkova. (2017). FAS Offers Putin Decree to Reduce the Presence of the State in the Economy. Vedomosti, February 8.

15. Analytical Credit Rating Agency "ACRA: State Share in Banking Sector reaches 70\%", February 14, 2018. https://acraratings.ru/about/articles/301

16. Andrei Polunin, "Russia Played a Monopoly: The Share of State-Owned Companies in the Country's GDP Grew to 70 percent", Free Press, September 29, 2016

17. Bernier, L. (Ed.). (2014). Public Enterprises Today: Missions, Performance and Governance-Les Entreprises Publiques Aujourd'hui: Missions, Performance, Gouvernance: Learning from Fifteen CasesLeçons de Quinze Études de Cas. PIE-Peter Lang SA, Éditions Scientifiques Internationales.

18. Smith, A. (1795). Essays on philosophical subjects. London: T. Cadell Jun. and W. Davies. 